\title{
Klasifikasi Kabupaten di Provinsi Jawa Timur Berdasarkan Indikator Daerah Tertinggal dengan metode Support Vector Machine (SVM) dan Entropy Based Fuzzy Support Vector Machine (EFSVM)
}

\author{
Jefry Pranata Maulana dan Irhamah \\ Departemen Statistika, Fakultas Matematika, Komputasi, dan Sains Data \\ Institut Teknologi Sepuluh Nopember (ITS) \\ Jl. Arief Rahman Hakim, Surabaya 60111 Indonesia \\ e-mail: irhamahn@gmail.com
}

\begin{abstract}
Abstrak- Pemerintah menetapkan 4 Kabupaten dari 29 kabupaten di Provinsi Jawa Timur masuk dalam kategori daerah tertinggal pada tahun 2015. Penelitian ini akan digunakan metode Entropy Based Fuzzy Support Vector Machine (EFSVM) dan Support Vector Machine (SVM) untuk mengklasifikasikan kabupaten di Provinsi Jawa Timur dengan dan tanpa seleksi variabel. Terdapatnya imbalance pada data deerah tertinggal dimana kabupaten tertinggal jauh lebih sedikit dibandingkan kabupaten tidak tertinggal memerlukan metode klasifikasi untuk data imbalance, Salah satunya adalah EFSVM. Hasil menunjukan EFSVM memiliki Kinerja yang lebih baik pada AUC dibandingkan dengan SVM.. Seleksi variabel mampu meningkatkan AUC pada EFSVM namun tidak meningkatkan AUC pada SVM.
\end{abstract}

Kata Kunci- Daerah Tertinggal, Data Imbalance, Entropy Fuzzy, Support Vector Machine (SVM)

\section{PENDAHULUAN}

Daerah tertinggal adalah daerah kabupaten yang wilayah serta masyarakatnya kurang berkembang dibandingkan dengan daerah lain dalam skala nasional [1]. Pemerintah menetapkan 4 Kabupaten pada Provinsi Jawa Timur masuk dalam kategori daerah yang tertinggal. Kabupaten tersebut adalah Kabupaten Situbondo, Kabupaten Bondowoso, Kabupaten Bangkalan, dan Kabupaten Sampang.

Pemerintah menetapkan daerah yang relatif kurang berkembang dibandingkan daerah lain dalam skala nasional sebagai daerah tertinggal. Dalam penetapan daerah tertinggal tahun 2015-2019 berdasarkan pada 6 (enam) indikator yaitu perekonomian masyarakat, kualitas dari sumberdaya manusia, prasarana, kemampuan keuangan lokal, aksesibilitas, dan karakteristik dari daerah. Masing-masing indikator terdapat sub indikator, sehingga terdapat 27 subindikator penetapan daerah tetinggal. Pemerintah menetapkan daerah menjadi tertinggal menggunakan beberapa pendekatan. Pendekatan dilakukan melalui analisa data seluruh kabupaten yang telah ditetapkan menjadi daerah tertinggal berdasarkan ketersediaan pada data-data terakhir daerah tersebut [1].

Penelitian-penelitian sebelumnya mengenai klasifikasi daerah tertinggal pernah dilakukan oleh Purwandari dan Hidayat [2] yang menggunakan Regresi Logistik Biner dengan hasil variabel yang signifikan adalah persentase penduduk miskin dan angka harapan hidup. Sebagian kekurangan dari metode-metode diatas adalah tidak mempertimbangkan terdapatnya imbalance pada data tersebut jumlah respon daerah tertinggal cenderung lebih sedikit dibandingkan dengan daerah tidak tertinggal. Salah satu metode klasifikasi untuk data imbalance adalah Entropy Based Fuzzy Support Vector Machine (EFSVM). EFSVM merupakan salah satu bentuk perluasan dari Support Vector Machine (SVM) yang menerapkan keanggotaan fuzzy berdasarkan entropy [3]. Penelitian ini bertujuan untuk klasifikasi data imbalance kabupaten - kabupaten di Provinsi Jawa Timur berdasarkan indikator daerah tertinggal dengan Support Vector Machine dan Entropy based fuzzy support vector machine dengan membandingkan nilai akurasi, sensitivity, specificity, dan AUC .

\section{TINJAUAN PUSTAKA}

\section{A. Fast Correlation Based Filter (FCBF)}

Fast Correlation Based Filter (FCBF) merupakan salah satu algoritma feature selection yang bersifat multivariate dan mengukur kelas variabel dan korelasi antara variabel-variabel berdasarkan nilai entropy [4]. Entropy dari variabel X dengan observasi sebanyak $\mathrm{n}$ didefinisikan pada Persamaan berikut.

$$
H(X)=-\sum_{i=1}^{n} P\left(x_{i}\right)^{2} \log \left(P\left(x_{i}\right)\right), i=1,2, \ldots, n
$$

B. Support vector machine (SVM)

Support vector machine (SVM) pertama kali dikenalkan oleh Vapnik pada tahun 1992 . Prinsip dasar SVM adalah linier classifier, yaitu kasus klasifikasi yang secara linier dapat dipisahkan dan memaksimalkan batas- batas hyperplane [5].. Metode Support Vector Machine (SVM) melakukan klasifikasi himpunan vektor training berupa set data data berpasangan dari dua kelas [5].

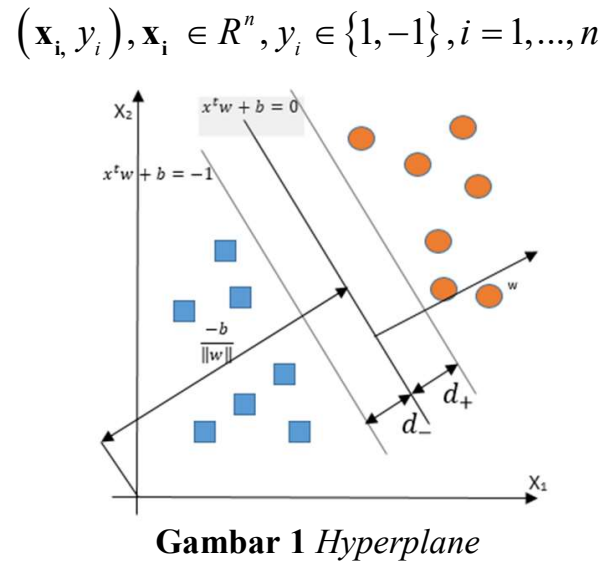

Gambar 1 Hyperplane 
$\mathbf{x}_{\mathbf{i}}^{\prime} \mathbf{W}+b=0$ adalah hyperplane pemisah. $d_{\text {- dan }} d_{+}$ akan menjadi jarak terpendek dari objek paling dekat dari kelas -1 dan +1 . Semua observasi harus memenuhi constraint

$$
\begin{aligned}
& \mathbf{x}_{\mathbf{i}}^{\prime} \mathbf{w}+b \geq+1 \text { untuk } \mathrm{y}_{\mathrm{i}}=+1 \\
& \mathbf{x}_{\mathrm{i}}^{\prime} \mathbf{w}+b \geq-1 \text { untuk } \mathrm{y}_{\mathrm{i}}=-1
\end{aligned}
$$

Kedua constraint dapat disederhanakan sebagai berikut

$$
y_{i}\left[\left(\mathbf{w}^{\prime} \mathbf{x}_{\mathbf{i}}\right)+b\right] \geq 1, i=1,2, \ldots n
$$

Garis pembatas pertama $\quad \mathbf{x}_{\mathbf{i}}^{\prime} \mathbf{w}+b=1$ mempunyai bobot dan jarak tegak lurus dari titik asal sebesar

$$
\frac{|1-b|}{\|\mathbf{w}\|}
$$

garis pembatas kedua $\mathbf{x}_{\mathbf{i}}^{\prime} \mathbf{w}+b=-1$ mempunyai bobot dan jarak tegak lurus dari titik asal sebesar

$$
\frac{|-1-b|}{\|\mathbf{w}\|} \text {. }
$$

Nilai maksimum margin atau nilai jarak antar bidang pembatas adalah $\frac{1-b-(-1-b)}{\|\mathbf{w}\|}=\frac{2}{\|\mathbf{w}\|}$.

Hyperplane yang paling optimal diperoleh dengan meminimumkan $\frac{1}{2}\|\mathbf{w}\|^{2}$ atau meminimumkan fungsi objektif

$$
\min \frac{1}{2} \mathbf{w}^{\prime} \mathbf{w}
$$

constraint

$$
y_{i}\left[\left(\mathbf{w}^{\prime} \mathbf{x}_{\mathbf{i}}\right)+b\right] \geq 1, i=1,2, \ldots n
$$

Misalkan terdapat Hyperplane yang optimal diperoleh denga meminimumkan $\frac{1}{2} \mathbf{w}^{\prime} \mathbf{w}$ dengan batasan $y_{i}\left[\left(\mathbf{w}^{\prime} \mathbf{x}_{\mathbf{i}}\right)+b\right] \geq 1, i=1,2, \ldots n$ [1]. Permasalahan optimasi minimum diatas dapat dibentuk sebagai fungsi lagrange multiplier primal sebagai berikut.

$$
L_{p}(\mathbf{w}, b, \alpha)=\frac{1}{2} \mathbf{w}^{\prime} \mathbf{w}-\sum_{i=1}^{n} \alpha_{i}\left[y_{i}\left(\mathbf{w}^{\prime} \mathbf{x}_{\mathbf{i}}+b\right)-1\right](10)
$$

Bentuk dual dari persamaan adalah sebagai berikut

$$
L_{d}(\alpha)=\sum_{i=1}^{n} \alpha_{i}-\frac{1}{2} \sum_{i=1}^{n} \sum_{j=1}^{n} \alpha_{i} \alpha_{j} y_{i} y_{j} \mathbf{x}_{i}^{\prime} \mathbf{x}_{\mathbf{j}}
$$

Optimasi didapatkan dengan menghitung Persamaan (11) dengan mendapatkan nilai $\alpha$

$$
\begin{aligned}
L_{d}(\alpha) & =\sum_{i=1}^{n} \alpha_{i}-\frac{1}{2} \sum_{i=1}^{n} \sum_{j=1}^{n} \alpha_{i} \alpha_{j} y_{i} y_{j} \mathbf{x}_{i}^{\prime} \mathbf{x}_{\mathrm{j}} \\
& =\alpha_{1}+\alpha_{2}+\alpha_{3}+\ldots+\alpha_{n}-\frac{1}{2} \alpha_{1} \alpha_{2} y_{1} y_{2} \mathbf{x}_{1}^{\prime} \mathbf{x}_{2}
\end{aligned}
$$

$$
-\frac{1}{2} \alpha_{1} \alpha_{3} y_{1} y_{3} \mathbf{x}_{1}^{\prime} \mathbf{x}_{3}-\ldots-\frac{1}{2} \alpha_{n-1} \alpha_{n} y_{n-1} y_{n} \mathbf{x}_{n-1}^{\prime} \mathbf{x}_{n}
$$

Selanjutnya $L_{d}$ diturunkan terhadap $\alpha_{1}, \alpha_{2}, \alpha_{3, .}$ $\alpha_{\mathrm{n}}$ sebagai berikut

$\frac{\partial L}{\partial \alpha_{1}}=1-\frac{1}{2} \alpha_{2} y_{1} y_{2} \mathbf{x}_{1}^{\prime} \mathbf{x}_{2}-\frac{1}{2} \alpha_{3} y_{1} y_{3} \mathbf{x}_{1}^{\prime} \mathbf{x}_{3}-\ldots-\frac{1}{2} \alpha_{n} y_{1} y_{n} \mathbf{x}_{1}^{\prime} \mathbf{x}_{n}$

$\frac{\partial L}{\partial \alpha_{2}}=1-\frac{1}{2} \alpha_{1} y_{1} y_{2} \mathbf{x}_{2}^{\prime} \mathbf{x}_{1}-\frac{1}{2} \alpha_{3} y_{2} y_{3} \mathbf{x}_{2}^{\prime} \mathbf{x}_{3}-\ldots-\frac{1}{2} \alpha_{n} y_{2} y_{n} \mathbf{x}_{2}^{\prime} \mathbf{x}_{n}$

$\frac{\partial L_{u}}{\partial \alpha_{n}}=1-\frac{1}{2} \alpha_{1} y_{1} y_{n} \mathbf{x}_{n}^{\prime} \mathbf{x}_{1}-\frac{1}{2} \alpha_{2} y_{2} y_{n} \mathbf{x}_{n}^{\prime} \mathbf{x}_{2}-\ldots \frac{1}{2} \alpha_{n-1} y_{n-1} y_{n} \mathbf{x}_{n}^{\prime} \mathbf{x}_{n-1}$

Nilai $\alpha_{1}, \alpha_{2}, \alpha_{3, \ldots} \alpha_{\mathrm{n}}$ diperoleh dengan menghitung sistem persamaan diatas dan didapatkan nilai $\mathbf{w}$ dan $b$ sebagai berikut

$$
\begin{gathered}
\mathbf{w}=\sum_{i=1}^{n} \alpha_{i} y_{i} \mathbf{x}_{\mathbf{i}} \\
b=y_{i}-\sum_{i=1}^{n} \alpha_{i} y_{i} \mathbf{x}_{i}^{\prime} \mathbf{x}_{\mathbf{j}}
\end{gathered}
$$

Fungsi hyperplane yang terbentuk adalah

$$
f(x)=\operatorname{sign}\left(\mathbf{w}^{\prime} \mathbf{x}+b\right)
$$

Nilai sign menunjukan jika nilai $f(x) \geq 0$ maka $f(x)=+1$, jika meiliki nila $f(x)<0$ maka $f(x)=-1$

.Pada kasus non-linier SVM, pertama-tama data $\mathbf{x}_{i}$ dipetakan oleh fungsi $\varphi\left(\mathbf{x}_{\mathbf{i}}\right)$ ke ruang vektor yang berdimensi lebih tinggi dan membutuhkan fungsi kernel $K\left(\mathbf{x}_{\mathbf{i}}, \mathbf{x}_{\mathbf{j}}\right)$. $\mathbf{x}_{\mathbf{i}}$ adalah nilai variabel $\mathbf{x}$ pada pengamatan ke $i$ dan $\mathbf{x}_{\mathbf{j}}$ adalah nilai variabel $\mathbf{x}$ pada pengamatan ke $j$. Fungi kernel akan menghasilkan matriks kernel yang berukuran $\mathrm{n} \times \mathrm{n}$ dengan $\mathrm{n}$ adalah banyaknya pengamatan/observasi. Beberapa fungsi dari kernel yang umum digunakan pada Support Vector Machine (SVM) adalah kernel linier, kernel Radial Basis Function, kernel sigmoid, dan kernel polinomial seperti pada persamaan berikut ini.

1. Kernel linier

$$
K\left(\mathbf{x}_{\mathbf{i}}, \mathbf{x}_{\mathbf{j}}\right)=\mathbf{x}_{i}^{\prime} \mathbf{x}_{\mathbf{j}}
$$

2. Kernel Radial Basis function

$$
K\left(\mathbf{x}_{\mathbf{i},} \mathbf{x}_{\mathbf{j}}\right)=\exp \left(-\gamma\left\|\mathbf{x}_{\mathbf{i}}-\mathbf{x}_{\mathbf{j}}\right\|^{2}\right), \gamma>0
$$

3. Kernel Polinomial

$$
K\left(\mathbf{x}_{\mathbf{i}}, \mathbf{x}_{\mathbf{j}}\right)=\left(\gamma \mathbf{x}_{i}^{\prime} \mathbf{x}_{\mathbf{j}}+r\right)^{p}, \gamma>0
$$




\section{Kernel Sigmoid}

$$
K\left(\mathbf{x}_{\mathbf{i}}, \mathbf{x}_{\mathbf{j}}\right)=\tanh \left(\gamma \mathbf{x}_{\mathbf{i}}^{\prime} \mathbf{x}_{\mathbf{j}}+r\right)
$$

Pemilihan jenis kernel akan berpengaruh kepada nilai akurasi, sensitivity, specificity, dan AUC. fungsi kernel yang direkomendasikan untuk diuji pertama kali adalah fungsi kernel RBF karena dapat memetakan hubungan tidak linear [1] . Nilai $\mathbf{w}, \mathbf{b}$, dan fungsi hyperplane adalah sebagai berikut

$$
\begin{gathered}
\mathbf{w}=\sum_{i=1}^{n} \alpha_{i} y_{i} \varphi\left(\mathbf{x}_{\mathbf{i}}\right) ; b=y_{i}-\sum_{i=1}^{n} \alpha_{i} y_{i} K\left(\mathbf{x}_{\mathbf{i}}, \mathbf{x}_{\mathbf{j}}\right) \\
f(x)=\operatorname{sign}\left(\sum_{i=1}^{n} \alpha_{i} y_{i} \varphi(\mathbf{x})^{\prime} \varphi(\mathbf{x})+b\right) \\
=\operatorname{sign}\left(\sum_{i=1}^{n} \alpha_{i} y_{i} K\left(\mathbf{x}_{\mathbf{i}}, \mathbf{x}_{\mathbf{j}}\right)+b\right)
\end{gathered}
$$

C. Klasifikasi dengan Entropy Fuzzy Support Vector Machine (EFSVM)

Perbedaan antara metode SVM dan EFSVM terdapatnya pada nilai pembobot $\mathrm{S}_{\mathrm{i}}$ pada parameter cost [4]. Perbedaan antara SVM dan SVM dengan penambahan keanggotaan fuzzy terletaak pada penerapan fuzzy membership $\left(s_{i}\right)$. Nilai $s i$ yang lebih kecil mengurangi efek dari parameter cost pada persamaan sehingga sampel $\mathbf{x}_{\mathbf{i}}$ dikurangi kepentingannya [4].

D Evaluasi Kinerja Klasifikasi

Pengukuran kinerja klasifikasi dilakukan untuk mengetahui kinerja klasifikasi untuk memprediksikan kelas suatu data. Hasil dari jumlah obervasi yang benar atau salah dari model Support Vector Machine (SVM) diklasifikasikan oleh model dapat disusun dalam sebuah confusion matrix berikut.

Tabel 1. confusion matrix

\begin{tabular}{lll}
\hline \multirow{2}{*}{ Kelas Aktual } & \multicolumn{2}{l}{ Kelas Prediksi } \\
\cline { 2 - 3 } & Positif & Negatif \\
\hline Positif & TP & FN \\
\hline Negatif & FP & TN \\
\hline
\end{tabular}

Keterangan:

TP : Banyaknya prediksi benar pada kelas positif

FP : Banyaknya prediksi salah pada kelas positif

$\mathrm{TN}$ : Banyaknya prediksi benar pada kelas negatif

FN : Banyaknya prediksi salah pada kelas negatif

Berdaarkan tabel confusion matrix dapat dihitung Nilai Akurasi, Sensitivity, Specificity dan AUC adalah sebagai berikut

$$
\begin{gathered}
\text { Akurasi }=\frac{T N+T P}{T N+T P+F N+F P} \\
\text { Sensitivity }=\frac{T P}{T P+F N} \\
\text { Specificity }=\frac{T N}{T N+F P}
\end{gathered}
$$

$$
A U C=\frac{1}{2}(\text { sensitivity }+ \text { specificity }) \times 100 \%
$$

\section{E Daerah Tertinggal}

Daerah tertinggal adalah daerah kabupaten yang wilayah serta masyarakatnya kurang berkembang dibandingkan dengan daerah lain dalam skala nasional [6]. Penentuan sebuah kabupaten tertinggal ditentukan beberapa indikator sebagai berikut.

a. Persentase Penduduk Miskin

Penduduk yang memiliki rata-rata pengeluaran perkapita per bulan dibawah Garis Kemiskinan dikategorikan sebagai penduduk miskin. Garis Kemiskinan (GK) merupakan penjumlahan dari Garis Kemiskinan Makanan (GKM) dan Garis Kemiskinan Non Makanan (GKNM) [7].

b. Pengeluaran per kapita per tahun disesuaikan

Pengeluaran per kapita per tahun yang disesuaikan ditentukan dari nilai pengeluaran per kapita dan paritas daya beli. Paritas daya beli pada metode baru menggunakan 96 komoditas dimana 66 komoditas merupakan makanan dan sisanya adalah komoditas nonmakanan [7].

c. Angka Harapan Hidup

Angka Harapan Hidup secara konsepsi diartikan sebagai rata-rata jumlah tahun hidup yang dapat dijalani oleh seseorang hingga akhir hayatnya [7]. Angka Harapan Hidup dihitung dari penjumahan usia orang meninggal pada tahun tersebut dibagi dengan banyaknya orang meninggal Rumus dari angka harapan hidup adalah sebagai berikut.

Angka Harapan Hidup $=\frac{U_{s i a_{1}}+U_{s i a_{2}}+\ldots+U_{s i a}}{n_{k}}$

$\mathrm{n}_{\mathrm{k}}=$ banyaknya orang meninggal per tahun

d. Rata-rata Lama Sekolah

Rata-rata Lama Sekolah (RLS), didefinisikan sebagai jumlah tahun yang digunakan oleh penduduk dalam menjalani pendidikan formal. Cakupan dari penduduk yang dihitung RLS adalah penduduk berusia 25 tahun ke atas. RLS dihitung untuk usia 25 tahun ke atas dengan asumsi pada umur 25 tahun proses pendidikan telah berakhir [7].

e. Angka Melek Huruf

Angka Melek Huruf adalah perbandingan jumlah penduduk usia 15 tahun keatas yang dapat membaca dan menulis huruf latin maupun huruf lainnya terhadap seluruh penduduk usia 15 tahun keatas dikali dengan seratus [1]. Hasilnya jika semakin besar akan semakin baik atau menggambarkan kondisi/tingkat kesejahteraan yang lebih baik

f. Jumlah desa dengan jenis permukaan jalan terluas

Jenis Permukaan jalan terluas adalah jenis permukaan jalan aspal/beton, diperkeras (dengan kerikil atau batu), tanah, dan lainnya yaitu terbuat dari kayu /papan yang biasanya digunakan di daera rawa, termasuk jalan setapak, jalan di hutan dan sejenisnya [1].

g. Indeks Desa Membangun 
Indeks Desa Membangun (IDM) merupakan ukuran untuk tingkat kemajuan desa pada suatu kabupaten. Semakin rendah nilai IDM maka semakin banyak desa yang berstatus sebagai desa tertinggal di kabupaten tersebut [1].

h. Indeks Kapasitas Fiskal

Indeks Kapasitas Fiskal indeks yang menunjukan kemampuan keuangan masing-masing daerah yang dicerminkan melalui penerimaan dana umum Anggaran Pendapatan dan Belanja Daerah (tidak termasuk dana alokasi khusus, dana darurat, dana pinjaman lama, dan penerimaan-penerimaan lain yang penggunaannya dibatasi untuk membiayai pengeluaran tertentu) [3].

\section{METODOLOGI PENELITIAN}

\section{A. Sumber Data}

Data yang digunakan dalam penelitian ini diperoleh dari Statistik Potensi Daerah 2014 [7], Profil Kesehatan Provinsi Jawa Timur 2014 [8-9] serta Realisasi Kemampuan Keuangan Daerah Tahun 2014 [10-11]. Unit penelitian ini adalah kabupaten.

\section{B. Variabel Penelitian}

Variabel-variabel yang digunakan pada penelitian ini disajikan pada Tabel 2 berikut.

\begin{tabular}{|c|c|c|c|}
\hline Variabel & Keterangan & Skala & Satuan \\
\hline Y & $\begin{array}{l}Y=-1 \text { (Daerah Tidak terting- } \\
\text { gal) } \\
Y=+1 \text { (Daerah tertinggal) }\end{array}$ & Nominal & Desa \\
\hline $\mathrm{X}_{1}$ & Persentase penduduk miskin & Rasio & Persentase \\
\hline $\mathrm{X}_{2}$ & $\begin{array}{l}\text { Pengeluaran per kapita yang } \\
\text { disesuaikan }\end{array}$ & Rasio & Rupiah \\
\hline $\mathrm{X}_{3}$ & Angka Harapan hidup & Rasio & Tahun \\
\hline $\mathrm{X}_{4}$ & Rata-rata lama Sekolah & Rasio & Tahun \\
\hline $\mathrm{X}_{5}$ & Angka Melek Huruf & Rasio & Persentase \\
\hline $\mathrm{X}_{6}$ & $\begin{array}{l}\text { Jumlah desa dengan jenis } \\
\text { permukaan jalan terluas } \\
\text { aspal/beton }\end{array}$ & Rasio & Desa \\
\hline $\mathrm{X}_{7}$ & $\begin{array}{l}\text { Jumlah desa dengan jenis } \\
\text { permukaan jalan terluas } \\
\text { diperkeras }\end{array}$ & Rasio & Desa \\
\hline $\mathrm{X}_{8}$ & $\begin{array}{l}\text { Jumlah desa dengan jenis } \\
\text { permukaan jalan terluas tanah }\end{array}$ & Rasio & Desa \\
\hline $\mathrm{X}_{9}$ & $\begin{array}{l}\text { Persentase rumah tangga } \\
\text { pengguna listrik }\end{array}$ & Rasio & Persentase \\
\hline $\mathrm{X}_{10}$ & $\begin{array}{l}\text { Persentase rumah tangga } \\
\text { pengguna telepon }\end{array}$ & Rasio & Persentase \\
\hline $\mathrm{X}_{11}$ & $\begin{array}{l}\text { Persentase rumah tangga } \\
\text { pengguna air bersih }\end{array}$ & Rasio & Persentase \\
\hline $\mathrm{X}_{12}$ & $\begin{array}{l}\text { Jumlah prasarana kesehatan } \\
\text { per } 1000 \text { penduduk }\end{array}$ & Rasio & Prasarana \\
\hline $\mathrm{X}_{13}$ & $\begin{array}{l}\text { Jumlah desa yang memiliki } \\
\text { pasar tanpa bangunan per- } \\
\text { manen }\end{array}$ & Rasio & Pasar \\
\hline $\mathrm{X}_{14}$ & $\begin{array}{l}\text { Jumlah dokter per } 1000 \\
\text { penduduk }\end{array}$ & Rasio & Orang \\
\hline $\mathrm{X}_{15}$ & $\begin{array}{l}\text { Jumlah SD dan SMP per } \\
1000 \text { penduduk }\end{array}$ & Rasio & Sekolah \\
\hline $\mathrm{X}_{16}$ & persentase desa gempa bumi & Rasio & Persentase \\
\hline$X_{17}$ & persentase desa tanah longsor & Rasio & Persentase \\
\hline $\mathrm{X} 18$ & persentase desa banjir & Rasio & persentase \\
\hline X19 & $\begin{array}{l}\text { persentase desa bencana } \\
\text { lainnya }\end{array}$ & Rasio & persentase \\
\hline $\mathrm{X} 20$ & $\begin{array}{l}\text { persentase desa di kawasan } \\
\text { hutan lindung }\end{array}$ & Rasio & persentase \\
\hline $\mathrm{X} 21$ & $\begin{array}{l}\text { persentase desa konflik satu } \\
\text { tahun terakhir }\end{array}$ & Rasio & persentase \\
\hline $\mathrm{X} 22$ & Indeks Kapasitas Fiskal & Rasio & Indeks \\
\hline $\mathrm{X} 23$ & Indeks Desa Membangun & Rasio & Indeks \\
\hline
\end{tabular}

C Langkah Analisis

Langkah-langkah analisis pada penelitian ini adalah sebagai berikut.
1. Statistika deskriptif untuk karakteristik data

2. Feature selection dengan metode FCBF

a. Menghitung Nilai entropy menggunakan persamaan

b. Menghitung nilai dari Information Gain dengan rumus sebagai berikut

$$
I G(X \mid Y)=H(X)-H(X \mid Y)
$$

3. Membagi data menjadi data testing dan data training.

4. Klasifikasi Data dengan Support Vector Machine (SVM).

a. Menentukan jenis dari fungsi kernel yang digunakan pemodelan menggunakan persamaan

b. Menentukan nilai initial value parameter kernel dan parameter cost untuk optimasi. Initial value berupa range dari parameter cost dan parameter dari fungsi kernel

c. Optimasi Parameter kernel dan parameter cost terbaik berdasarkan nilai AUC

5. Klasifikasi Data dengan Fuzzy Entropy Support Vector Machine

a. Menentukan k-Nearest Neighbors (k-NN) untuk masing-masing sampel

b. Menghitung jumlah sampel positif dan negatif pada (k-NN) .

c. Menghitung peluang dari sampel positif dan negatif

$$
p_{+i}=\frac{\text { num }_{+i}}{k} ; p_{-i}=\frac{n u m_{-i}}{k}
$$

d. Menghitung nilai entropy dari dari masing-masing data training

$$
H=-p_{+i} \ln \left(p_{+i}\right)-p_{-i} \ln \left(p_{-i}\right)
$$

e. Pada sampel training $\mathbf{x}_{\mathbf{i}}$ dari kelas negatif dikelompokan kedalam $m$ subset kemudian menghitung nilai pada batas atas (thrUp) dan nilai pada batas bawah (thrLow) dengan rumus sebagai berikut

$$
\begin{gathered}
\operatorname{thrUp}=H_{\min }+\frac{1}{m}\left(H_{\max }-H_{\min }\right) ; \\
\text { thrLow }=H_{\min }+\frac{l-1}{m}\left(H_{\max }-H_{\min }\right) .
\end{gathered}
$$

f. Setelah didapatkan nilai batas atas dan batas bawah pada masing-masing subset, sampel data training dari kelas negatif dikelompokan berdasarkan nilai entropy.

g. Menghitung nilai fuzzy membership untuk masing-masing subset

$$
F M_{l}=1.0-\beta *(l-1), l=1,2, \ldots, m
$$

h. Menetapkan entropy based fuzzy membership untuk semua training sampel $\mathrm{x}_{\mathrm{i}}$ menggunakan Sampel dari kelas positif diberi niai $\mathrm{s}_{\mathrm{i}}=1$, sedangkan untuk sampel dari kelas negatif memiliki nilai $s_{i}$ yang sesuai dengan telah dihitung pada langkah sebelumnya. Semakin tinggi nilai entropy, maka semakin mendekati satu nilai dari fuzzy membership. 
i. Optimasi Parameter kernel dan parameter cost terbaik berdasarkan nilai AUC. N

j. Membandingkan Kinerja hasil klasifikasi dengan metode SVM dan EFSVM berdasarkan nilai AUC. Dipilih perbandingan nilai AUC karena data yang dianalisis adalah data imbalance.

\section{ANALISIS DAN PEMBAHASAN}

A. Karakteristik Data Daerah Tertinggal

Terdapat 29 Kabupaten di Provinsi Jawa Timur. Sebanyak 4 kabupaten atau sekitar 14\% dari total kabupaten di Provinsi Jawa Timur yang berstatus sebagai daerah tertinggal.

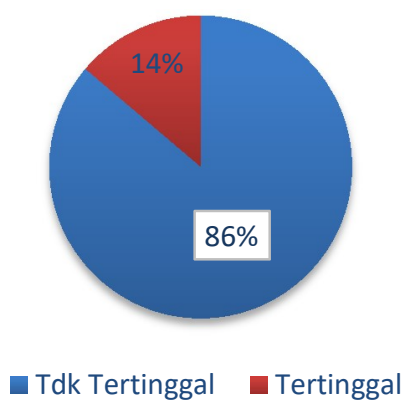

Gambar 2 Proporsi Kabupaten Tertinggal

Grafik diatas proporsi kelas kabupaten tertinggal lebih sedikit dibandingkan kelas kabupaten tidak tertinggal dengan rasio kelas mayoritas dibandingkan dengan kelas minoritas adalah 25:4 yang menunjukkan kategori low imbalance.

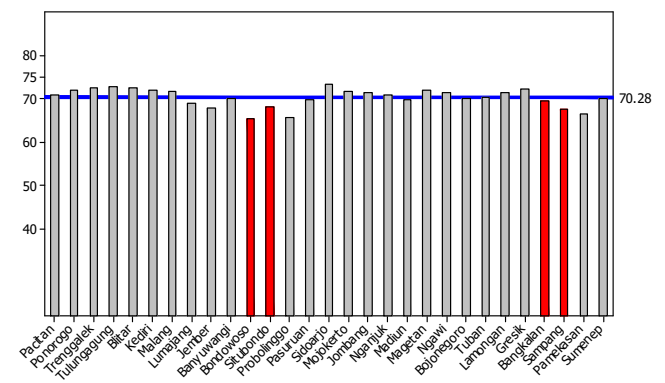

Gambar 3 Angka Harapan Hidup di Jawa Timur

Rata-rata angka harapan hidup di Provinsi Jawa Timur adalah 70,28 tahun . Grafik batang yang bewarna merah adalah kabupaten tertinggal. Semua kabupaten tertinggal memiliki angka harapan hidup di bawah rata-rata Jawa Timur.

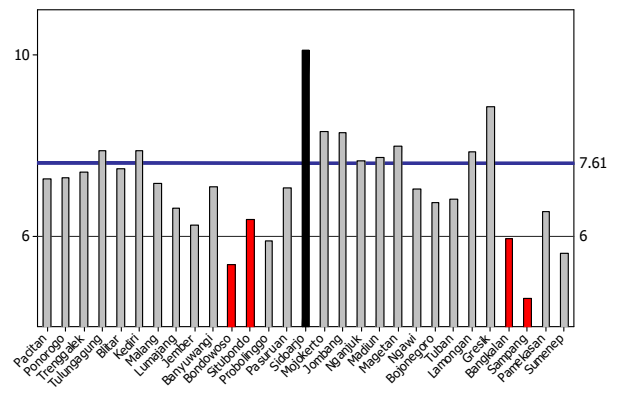

Gambar 4 Rata-rata lama sekolah

Rata-rata lama sekolah di Provinsi Jawa Timur pada masing-masing kabupaten dapat dilihat pada
Gambar 3 dengan bewarna merah adalah kabupaten tertinggal. Kabupaten Sodoarjo memiliki rata-rata lama sekolah sebesar 10,12 tahun yang merupakan kabupaten nilai rata-rata lama sekolah tertinggi. Terdapat tiga Kabupaten tertinggal yaitu Kabupaten Bondowoso, Kabupaten Bangkalan dan Kabupaten Sampang bahkan memiliki rata-rata lama sekolah kurang dari 6 tahun sehingga dapat disimpulkan ratarata penduduk yang berumur 25 tahun keatas hanya bersekolah kurang dari 6 tahun atau tidak tamat pendidikan sekolah dasar. Secara umum, rata-rata lama sekolah di Provinsi Jawa Timur terlihat sebesar 7,61 tahun.

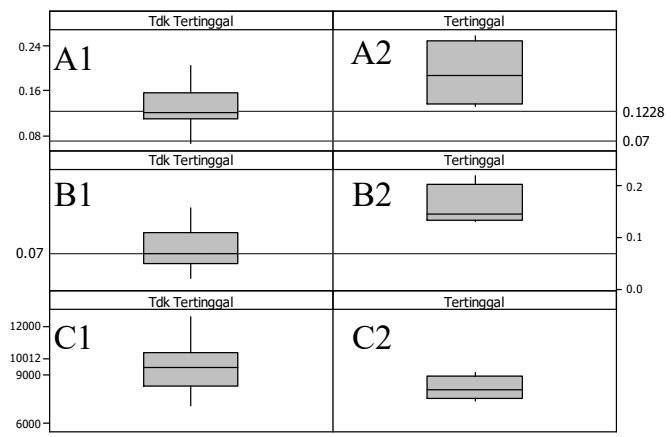

Gambar 5 Boxplot persentase penduduk miskin (A), ang-

ka tidak melek huruf (B), dan konsumsi per kapita (C)

Pada Boxplot $\mathrm{C}$ menunjukkan konsumsi per kapita di semua kabupaten tertinggal memiliki nilai yang lebih rendah dari angka konsumsi per kapita Jawa Timur yang sebesar Rp 10.012, Pada Boxplot $\mathrm{B}$, kabupaten tertinggal memiliki angka tidak melek huruf yang jauh lebih tinggi dari angka nasional Jawa Timur yaitu sebesar 0,07 . Semakin besar angka tidak melek huruf, maka semakin banyak penduduk yang berusia 15 tahun keatas yang tidak bisa membaca dan menulis huruf latin di kabupaten tersebut. Persentase penduduk miskin pada kabupaten yang tertinggal pada Boxplot A memiliki nilai yang lebih tinggi dari kabupaten-kabupaten lain yang tidak tertinggal.

Penyebaran data dari beberapa variabel terdapat pada gambar 6. Terdapat pola data yang menyebar sehingga sehingga sulit dipsahkan fungsi pemisah linier sehingga diperlukan bantuan kernel untuk mendapatkan fungsi pemisah yang optimal

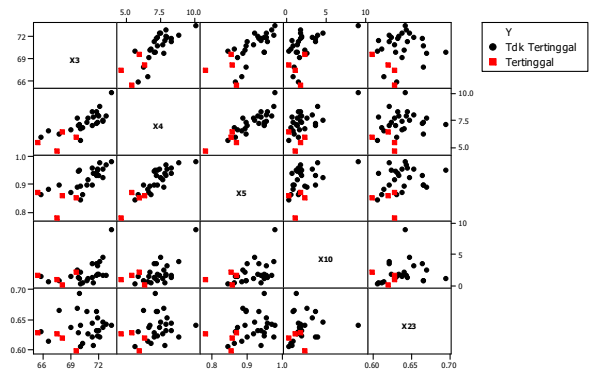

Gambar 6 Pola persebaran data beberapa variabel

B Seleksi Variabel dengan Fast Correlation Based Filter (FCBF)

Seleksi fitur dengan Fast Correlation Based Filter $(F C B F)$ dilakukan dengan cara memilih fitur-fitur yang relevan yang mempengaruhi hasil klasifikasi. Hasil dari seleksi fitur dengan metode FCBF terdapat pada tabel 3. Variabel yang terpilih adalah Angka 
melek huruf, Rata rata lama sekolah, persentase pengguna listrik dan angka harapan hidup

Tabel 3 Variabel terpilih hasil FCBF

\begin{tabular}{clc}
\hline No & \multicolumn{1}{|c}{ Nama Variabel } & $\begin{array}{c}\text { Information } \\
\text { Gain }\end{array}$ \\
\hline 1 & Angka melek huruf & 0,341 \\
\hline 2 & Rata-rata lama sekolah & 0,341 \\
\hline 3 & $\begin{array}{l}\text { Persentase rumah tangga } \\
\text { pengguna listrik }\end{array}$ & 0,341 \\
\hline 4 & Angka Harapan Hidup & 0,303 \\
\hline
\end{tabular}

Information Gain pada variabel angka harapan hidup adalah yang terendah yaitu sebesar 0,303 .

C Pembagian data training dan testing dengan Stratified K-Fold Cross Validation

$\mathrm{K}$-fold yang digunakan dalam penelitian ini adalah sebanyak 4 fold. Berikut adalah hasil pembagian 4 fold.

Tabel 4 Hasil Kfold Cross Validation

\begin{tabular}{ll}
\hline Fold & Anggota \\
\hline Fold 1 & $10,5,22,15,23, \mathbf{1 2}, 17$ \\
Fold 2 & $28,14,2,6,29, \mathbf{1 1}, 19$ \\
Fold 3 & $16,4,9,24,7, \mathbf{2 7}, 20$ \\
Fold 4 & $1,21,18,25, \mathbf{2 6}, 3,8,13$ \\
\hline
\end{tabular}

Berdasarkan Tabel 4, angka yang bercetak tebal adalah kabupaten tertinggal sehingga masing-masing fold memiliki satu kabupaten tertinggal. Kabupaten dengan data ke 12, 11, 27, dan 26 berturut urut adalah Kabupaten Situbondo, Kabupaten Bondowoso, Kabupaten Sampang, dan Kabupaten Bangkalan sedangkan sisanya adalah kabupaten-kabupaten lain yang tidak tertinggal. Penentuan k-fold menggunakan Stratified dimana pada masing-masing fold terdapat satu kabupaten tertinggal.

D Klasifikasi Kabupaten dengan Support Vector Machine (SVM)

Klasikasi dengan SVM dilakukan pada semua variabel dan variabel yang telah terseleksi pada Feature Correlation Based Filter . Nilai cost yang dipilih pada range $2^{-6}, 2^{-5}, 2^{-4}, \ldots 2^{1}, 2^{2}, \ldots 2^{5}, 2^{6}[4]$ dan nilai gamma yang dipilih pada range yang sama

Tabel 5 Hasil AUC dan Akurasi data training SVM (\%)

\begin{tabular}{cccccc}
\hline Kernel & Variabel & AUC & Akurasi & Cost & Gamma \\
\hline RBF & Semua & 100 & 100 & $2^{6}$ & $2^{-6}$ \\
RBF & Seleksi & 100 & 100 & $2^{6}$ & $2^{3}$ \\
\hline Linier & Semua & 50 & 86,20 & $2^{-6}$ & - \\
Linier & Seleksi & 100 & 100 & $2^{2}$ & - \\
\hline Sigmoid & Semua & 60,12 & 73,48 & $2^{5}$ & $2^{-4}$ \\
Sigmoid & Seleksi & 95,83 & 73,48 & $2^{4}$ & $2^{-6}$ \\
\hline
\end{tabular}

Berdasarkan Tabel 5, metode SVM dengan menggunakan kernel RBF memiliki nilai AUC yang tinggi yaitu sebesar $100 \%$ pada semua variabel dan seleksi variabel. Nilai AUC terendah didapatkan pada kernel linier dengan menggunakan semua variabel. Nilai AUC dihitung berdaarkan persamaan (23) Seleksi variabel menghasilkan nilai AUC yang lebih tinggi dari kernel linier dan kernel sigmoid. Hasil dari kinerja klasifikasi pada data testing ditampilkan pada Tabel 6.
Tabel 6 Hasil AUC dan Akurasi data testing (\%)

\begin{tabular}{cccccc}
\hline Kernel & Variabel & AUC & Akurasi & Sensitivity & Specificity \\
\hline RBF & Semua & 50 & 86,16 & 0 & 100 \\
RBF & Seleksi & 50 & 86,16 & 0 & 100 \\
\hline Linier & Semua & 50 & 86,16 & 0 & 100 \\
Linier & Seleksi & 34,52 & 56,25 & 0 & 65,48 \\
\hline Sigmoid & Semua & $\mathbf{6 6 , 9 6}$ & $\mathbf{7 9 , 4 6}$ & $\mathbf{5 0}$ & $\mathbf{8 3 , 9 3}$ \\
Sigmoid & Seleksi & 48,81 & 65,63 & 25 & $\mathbf{7 2 , 6 2}$ \\
\hline
\end{tabular}

Tabel 6 menunjukan nilai AUC tertinggi pada data testing terdapat pada SVM dengan menggunakan kernel sigmoid pada semua variabel. Nilai AUC daan sensitivity pada kernel RBF sebesar 50\% dan $0 \%$. Hal ini menunjukan SVM dengan kernel RBF hanya mampu mengklasifikasikan kabupaten yang tidak tertinggal dengan benar. Model yang terbentuk dapat dilihat pada Tabel 7. Pada data testing, metode SVM dengan menggunakan seleksi variabel tidak meningkatkan nilai AUC.

Tabel 7 Model SVM dari tiga jenis kernel

\begin{tabular}{cc}
\hline Kernel & Model \\
\hline RBF & $f(\mathbf{x})=\sum_{i=1}^{29} \sum_{i=1}^{29} \alpha_{i} y_{i} \exp \left(-2^{3}\left\|x_{i}-x_{j}\right\|^{2}-0.1190523\right)$ \\
Linier & $f(\mathbf{x})=\sum_{i=1}^{29} \sum_{i=1}^{29} \alpha_{i} y_{i}\left(x_{i}^{\prime} x_{j}+0.05041696\right)$ \\
Sigmoid & $f(\mathbf{x})=\sum_{i=1}^{29} \sum_{i=1}^{29} \alpha_{i} y_{i}\left(\tanh \left(2^{-4} \mathbf{x}_{i}^{\prime} \mathbf{x}_{i}+0\right)+0.003388564\right)$ \\
\hline RBF & $f(\mathbf{x})=\sum_{i=1}^{29} \sum_{i=1}^{29} \alpha_{i} y_{i} \exp \left(-2^{-3}\left\|x_{i}-x_{j}\right\|^{2}-0.1839123\right)$ \\
Linier & $f(\mathbf{x})=\sum_{i=1}^{29} \sum_{i=1}^{29} \alpha_{i} y_{i}\left(x_{i}^{\prime} x_{j}+0.3348949\right)$ \\
Sigmoid & $f(\mathbf{x})=\sum_{i=1}^{29} \sum_{i=1}^{29} \alpha_{i} y_{i}\left(\tanh \left(2^{-6} \mathbf{x}_{i}^{\prime} \mathbf{x}_{i}+0\right)-0.4186657\right)$ \\
\hline
\end{tabular}

E Klasifikasi Kabupaten dengan Entropy Based Fuzzy Support Vector Machine (EFSVM)

Parameter cost yang dipilih pada EFSVM adalah dipilih pada range $2^{-6}, 2^{-5}, 2^{-4}, \ldots 2^{-1}, 2^{1}, 2^{2}, \ldots 2^{6}$ [4]. Parameter gamma yang dipilih pada range $2^{-6}, 2^{-5}, 2^{-4}$ $, \ldots 2^{-1}, 2^{1}, 2^{2}, \ldots 2^{6}$. Hasil nilai AUC dan akurasi pada data training adalah sebagai berikut

Tabel 8 Hasil AUC dan Akurasi data training EFSVM (\%)

\begin{tabular}{cccccc}
\hline Kernel & Variabel & AUC & Akurasi & Cost & Gamma \\
\hline RBF & Semua & 97,98 & 96,54 & $2^{-5}$ & $2^{-4}$ \\
RBF & Seleksi & 93,31 & 88,47 & $2^{-4}$ & $2^{-5}$ \\
\hline Linier & Semua & 97,37 & 95,46 & $2^{-5}$ & - \\
Linier & Seleksi & 92,65 & 87,34 & $2^{-4}$ & - \\
\hline Sigmoid & Semua & 98,03 & 96,59 & $2^{-6}$ & $2^{-3}$ \\
Sigmoid & Seleksi & 93,31 & 88,47 & $2^{-5}$ & $2^{6}$ \\
\hline
\end{tabular}

Tabel 8 menunjukan nilai AUC yang didapatkan pada data training dengan menggunakan variabel seleksi memiliki nilai AUC yang lebih rendah dari AUC dari semua variabel. Hasil ini menunjukan seleksi variabel tidak meningkatkan nilai AUC pada data training. Nilai AUC tertinggi pada data training terdapat pada kernel sigmoid dengan menggunakan semua variabel. Hasil nilai AUC dan akurasi pada testing dapat dilihat seperti Tabel 9 
Tabel 9 Hasil kinerja data testing EFSVM (\%)

\begin{tabular}{cccccc}
\hline Kernel & Variabel & AUC & Akurasi & Sensitivity & Specificity \\
\hline RBF & Semua & 79,76 & 83,04 & 75 & 84,52 \\
RBF & Seleksi & $\mathbf{9 2 , 2 6}$ & $\mathbf{8 6 , 6 1}$ & $\mathbf{1 0 0}$ & $\mathbf{8 4 , 5 2}$ \\
\hline Linier & Semua & 65,48 & 76,79 & 50 & 80,95 \\
Linier & Seleksi & $\mathbf{9 2 , 2 6}$ & $\mathbf{8 6 , 6 1}$ & $\mathbf{1 0 0}$ & $\mathbf{8 4 , 5 2}$ \\
\hline Sigmoid & Semua & 65,48 & 76,79 & 50 & 80,95 \\
Sigmoid & Seleksi & 91,96 & 86,16 & 100 & 83,93 \\
\hline
\end{tabular}

Tabel 9 menunjukan metode Entropy Based Support Vector Machine (EFSVM) dengan menggunakan seleksi variabel kernel RBF dan kernel linier menghasilkan nilai AUC yang sama yaitu sebesar 92,26 \% yang merupakan AUC tertinggi . Hasil yang berbeda dari data training ternyata didapatkan seleksi variabel dengan Fast Correlation Based Filter (FCBF) ternyata mampu meningkatkan AUC pada data testing. Nilai Sensitivity sebesar 100 menunjukan model EFSVM mampu mengklasifikasikan semua kabupaten tertinggal dengan benar.

Hasil kinerja dari data testing terbaik dapat dilihat pada Tabel 10

Tabel 10 Evaluasi Kinerja Metode Klasifikasi (\%)

\begin{tabular}{cccccc}
\hline Metode & Kernel & AUC & Akurasi & Sensitivity & Specificity \\
\hline $\begin{array}{c}\text { SVM } \\
\text { Semua }\end{array}$ & Sigmoid & 66,96 & 79,46 & 50 & 83,93 \\
\hline $\begin{array}{c}\text { EFSVM } \\
\text { Seleksi }\end{array}$ & RBF & $\mathbf{9 2 , 2 6}$ & $\mathbf{8 6 , 6 1}$ & $\mathbf{1 0 0}$ & $\mathbf{8 4 , 5 2}$ \\
\hline $\begin{array}{c}\text { EFSVM } \\
\text { Seleksi }\end{array}$ & Linier & $\mathbf{9 2 , 2 6}$ & $\mathbf{8 6 , 6 1}$ & $\mathbf{1 0 0}$ & $\mathbf{8 4 , 5 2}$ \\
\hline
\end{tabular}

Pada Tabel 10 menunjukan klasifikasi terbaik dari model SVM hanya mempu mendapatkan nilai AUC sebesar $66,9 \%$ dengan akurasi sebesar $79,46 \%$. Metode EFSVM memiliki nilai sensitivity sebesar $100 \%$ yang berarti mampu mengklasifikasikan kelas minoritas dengan benar atau mampu mengklasifikasikan kabupaten tertinggal dengan benar.

\section{KESIMPULAN}

Hasil analisis dan pembahasan yang telah dipaparkan dapat diambil kesimpulan sebagai berikut. Hasil model terbaik klasifikasi data imbalance kabupaten di Provinsi Jawa Timur dengan meggunakan Indikator Daerah tertinggal tertinggal adalah dengan metode EFSVM dari variabel yang telah terseleksi dengan kernel Radial Basis Function (RBF) dan kernel linier. Seleksi variabel dengan menggunakan FCBF mampu meningkatkan nilai dari AUC pada metode Entropy Based Fuzzy Support Vector Machine (EFSVM) namun tidak meningkatkan nilai AUC pada metode Support Vector Machine. (SVM) Saran dari hasil penelitian diatas, diharapkan menggunakan data dengan jumlah data yang lebih. banyak yang memiliki perbandingan kelas minoritas dan mayoritas lebih besar. Perlu dilakukan perbandingan dengan metode EFSVM dengan nilai $\beta, m$, $k$ dan posisi kabupaten tertinggal pada masingmasing fold yang berbeda-beda.

\section{DAFTAR PUSTAKA}

[1] W. C. Hsu, C. C. Chang and C. J. Lin, A Practical Guide to Support Vector Machine., Taipei: Departement of Computer Science National Taiwan University, 2004.
[2] H. Liu and Y. Lei, "Feature Selection for High Dimensional Data : A Fast Correlation Based Filter Solution," Proceeding of Twentieth International Conference on Machine Learning (ICML-2003), 2003.

[3] N. Hasanah, Analisis Diskriminan untuk Evaluasi status Ketertinggalan Kabupaten, Bogor: Jurusan Statistika Institut Pertanian Bogor, 2009.

[4] V. Lisna, B. Sinaga, M. Firdaus and S. Sutomo, "Dampak Kapasitas Fiskal terhadap Penurunan Kemiskinan: Suatu Analisis Simulasi Kebijakan," Jurnal Ekonomi dan Pembangunan Indonesia, pp. 1-26, 2013.

[5] S. Gunn, Support Vector Machine for Clasification and Regression, Southamton: University of Southamton, 1998.

[6] Q. Fan, Z. Wang, D. Li, D. Gao and H. Zha, "Entropy Based Fuzzy Support Vector Machine for Imbalance Datasets," Knowledge Based System, pp. 87-99, 2017.

[7] Badan Pusat Statistik, Statistik Potensi Desa Jawa Timur, Jakarta: Badan Pusat Statistik., 2014.

[8] K. Desa, Rencana Strategis Direktorat Jenderal Pembangunan Daerah Tertinggal 2015-2019, Jakarta: Kementerian Desa, Pembangunan Daerah Tertinggal dan Transmigrasi, 2015.

[9] Dinas Kesehatan Provinsi Jawa Timur, Profil Kesehatan Provinsi Jawa Timur, Surabaya: Dinas Kesehatan Provinsi Jawa Timur, 2014 .

[10] Direktorat Jenderal Perimbangan Keuangan Kementerian Keuangan, Affirmative Policy Dalam Percepatan Pembangunan Daerah Untuk Meningkatkan Kesejahteraan Rakyat., Jakarta: Kementerian Keuangan, 2013.

[11] T. \&. H. Y. Purwandari, Pemodelan Ketertinggalan Daerah, Bandung: Jurusan Statistika, Universitas Padjadjaran, 2017. 